\title{
OPTIMISATION OF THE TECHNICAL OBJECT MAINTENANCE SYSTEM TAKING ACCOUNT OF RISK ANALYSIS RESULTS
}

\section{OPTYMALIZACJA SYSTEMU OBSŁUGI OBIEKTÓW TECHNICZNYCH Z UWZGLĘDNIENIEM WYNIKÓW ANALIZY RYZYKA*}

\begin{abstract}
The article presents the author's original method of optimisation of the technical object maintenance system taking account of risk analysis results. An original form of the objective function was formulated, in which a risk measure model based on two criteria was used. RBM methods were discussed and technical object maintenance methods/strategies were reviewed, with their most important characteristics pointed out. The process of making maintenance-related decisions is armed with procedures based on a risk valuation pattern. The author's original risk valuation pattern was presented and special cases resulting from the use of such patterns were discussed. Dynamic programming was used to solve the problem of optimisation. The author's original mathematical model of the method of optimisation was developed and presented, and its four-stage calculation algorithm was presented in detail. Based on the collected statistical data on damage, hazard analysis and risk assessment procedures were carried out. Using computer implementation of the optimisation model, an experiment in planning the maintenance of the technical objects examined was carried out and the results of the optimisation experiment were presented.
\end{abstract}

Keywords: optimisation, maintenance system, risk, risk based maintenance.

$W$ artykule przedstawiono autorska metodę optymalizacji systemu obstugi obiektów technicznych z uwzględnieniem wyników analizy ryzyka. Sformułowano oryginalna postać funkcji celu, w której użyto modelu miary ryzyka opartego na dwóch kryteriach. Omówiono metody RBM oraz dokonano przegladu metod/strategii obstugiwania obiektów technicznych wskazując ich najważniejsze cechy. Podejmowanie decyzji obstugowych uzbrojone jest w procedury oparte na schemacie wartościowania ryzyka. Przedstawiono autorski schemat wartościowania ryzyka i omówiono szczególne przypadki wynikajace z użycia takich schematów. Do rozwiązania problemu optymalizacji użyto programowania dynamicznego. Opracowano i przedstawiono autorski matematyczny model metody optymalizacji oraz szczegółowo zaprezentowano jego czteroetapowy algorytm obliczeniowy. Na podstawie zebranych danych statystycznych dotyczacych uszkodzeń, przeprowadzono procedury $w$ zakresie analizy zagrożeń $i$ oceny ich ryzyka. Wykorzystujac implementację komputerowa modelu optymalizacyjnego przeprowadzono eksperyment w zakresie planowania obstug rozpatrywanych obiektów technicznych oraz przedstawiono wyniki eksperymentu optymalizacyjnego.

Stowa kluczowe: optymalizacja, system obstugiwania, ryzyko, risk based maintenance.

\section{Introduction}

\subsection{Preliminary remarks on the subject matter}

In numerous organisations, the success of economic projects is conditioned by the level of readiness of technical object elements and their operation systems to perform the tasks imposed on them. The level of readiness of the objects and their components depends, among others, on the effectiveness of the adopted maintenance strategies and procedures. As the author of [30] states: "With the fast development of industry and the highly competitive international market, especially the areas of electronic products, nuclear power, automobile, shipbuilding, and aircraft, cost-effective and accurate maintenance shows increasing importance in improving plant production availability, reducing downtime cost, and enhancing operating reliability". For example - in manufacturing companies, maintenance costs amount to $15-70 \%$ of the total cost of production, where most of the maintenance activities function as corrective measures and are implemented primarily in situations particularly requiring their application [34].

In order to improve maintenance activities and decrease maintenance costs, maintenance process models have been under study in a broad scope since 1950 [39]. Thanks to this, numerous concepts or strategies of implementing these processes were created. In principle, they can be divided into two groups: corrective maintenance $(\mathrm{CM})$ and preventive maintenance (PM). Corrective maintenance is performed after damage is identified and its aim is to bring the element and the object to a condition in which they will be able to perform the required functions. This introduces certain limitations, however. For example, according to [30]: "corrective maintenance at its best should be utilized only in non-critical areas where capital costs are small, consequences of failure are slight, no safety risks are immediate, and quick failure identification and rapid failure repair are possible".

Preventive maintenance is performed according to a predetermined schedule or the number of work units (NWU) without previous examination of the condition of the object's elements. If the effects of a poor condition of the object are significantly greater than the effects/ costs of preventive activities and it is possible to observe the course of ageing of the object's elements, it is reasonable to use a PM-based strategy [27]. Moreover, as indicated by the author of [33], maintaining a high level of device reliability is achieved, among others, by maintenance work consisting in anticipatory replacement of elements at risk of damage. The advantage of applying PM is that it can be performed at scheduled dates, for example during breaks between the tasks performed. This lowers the risk of interruptions during the per-

(*) Tekst artykułu w polskiej wersji językowej dostępny w elektronicznym wydaniu kwartalnika na stronie www.ein.org.pl 
formance of tasks [27]. The authors of [30, 31] claim in general that a significant advantage of some of the PM-type methods is the creation of conditions for controlling object operation processes.

In the group of PM-type maintenance strategies, condition based maintenance (CBM) and predetermined maintenance can be distinguished. CBM is performed after previous verification or monitoring of the parameters of the object's operation. Monitoring may be continuous or carried out according to a specific schedule. In practice, however, effective application of CBM creates certain challenges. Firstly, its initiation is expensive. Hardware costs are often relatively high. In such case, it is important to decide whether the given element is significant enough to justify the investment. Secondly, making optimal maintenance decisions based on CBM is not always easy to achieve due to variables such as the complexity of the environment, the internal structure of the object, damage mechanisms not entirely known, etc. [30].

According to other authors (e.g. [36]), the following maintenance strategy categories can also be distinguished: age replacement policy, block replacement policy, periodic preventive maintenance policy, failure limit policy, sequential preventive maintenance policy, repair cost limit policy, repair time limit policy, repair number counting policy, reference time policy, mixed age policy, group maintenance policy, opportunistic maintenance policy, etc.

Moreover, the strategies can be divided, depending on the homogeneity of a set of object elements, into maintenance strategies for homogeneous and heterogeneous elements.

Regardless of the classification, it was observed that the following criteria are usually adopted when developing maintenance strategies $[13,40]$ :

- maximisation (in the long term) of the technical objects' readiness to perform the tasks imposed on them;

- minimisation of the operating costs of technical objects in the long term;

- maximisation of the technical objects' readiness to perform the tasks imposed on them and minimisation of the average operating costs of these objects in the long term.

The characteristics of technical object maintenance strategies indicated above were used to develop the method presented in this article.

\subsection{Risk Based Maintenance}

In a modern approach to technical object management, an approach based on the so-called risk management principles is used. As stated by Khan [25], the development of such methods occurred within the last dozen or so years. They are called risk based maintenance (RBM) methods. In various studies from the years 2003-2010 (e.g. [8, $12,10,11,25,28,37])$, examples of the application of RBM to various types of objects and their elements can be found. Currently (20112016), examples of such studies include: [2, 6, 15, 16, 17, 29, 38].

RBM finds application in particular in transport system objects [21]. Their damage or operating errors may generate hazards whose activation is manifested in serious losses - injuries, deterioration of health or loss of human life, considerable material losses, damage to the natural environment or loss of reputation. We can talk about particular importance/significance of such objects or their elements, justifying investments. The problem of the significance of object elements in CBM-type strategies was mentioned in the introduction (chapter 1). In such objects, the need to apply RBM was additionally forced by legislation. As e.g. Zio puts it [40]: "Obviously, occupational and public safety, environmental and other requirements must be satisfied as enforced by regulations". For example, in the EU railway transport system, it results from the CSM (common safety method) documents standardising the requirements and methods connected with the safety of the EU railway system. In accordance with these documents, railway companies, infrastructure administrators, and all the entities introducing changes to the railway system are responsible for maintaining the risk of all the identified hazards at levels below the non-acceptable risk category.

Some conditions of object elements should therefore be examined as the so-called hazard sources (also called hazard factors or risk factors). The term hazard source (HS) can be understood as formations, e.g. physical, chemical, biological, psychophysical, organisational or personal, whose presence in the given area of analysis, condition, properties, etc. are a source of hazard [21].

Identification of the HS may occur at consecutive stages of the objects' life cycle. On this basis, the so-called hazards (H) are formulated, which makes it possible to assess the impact of the damage to these objects on human life and health, the natural environment, and technical systems. This impact is expressed in units of risk level attributed to each hazard, adopting the appropriate risk model. A combination of the level of possibility or probability of hazard activation/ materialisation and the level of effects expressed in losses or damage caused by the event is usually adopted. There are numerous examples of such an approach, e.g. in $[1,3,4,7,10,16,35]$. It should be noted, however, that risk models may include many other components. They may, for example, take account of human errors in the maintenance processes, which was demonstrated, among others, by Hammeed in [15].

In this context of the problem, the organisation of technical object maintenance becomes particularly important. It can and should be treated as a means to achieve the acceptable or at least tolerable level of risk. The most effective, and at the same time most recommended ways of reducing hazard risk are those eliminating the HS. Proper organisation of maintenance meets this condition and in this sense, it may be treated as a tool or means of risk reduction.

Risk reduction measures are usually organised in the form of systems, mainly of a technical nature (e.g. alarm devices, physical covers, protection systems), but the use of measures of an organisational nature (e.g. a team of people acting according to predetermined procedures) is equally effective. The legitimacy of the use of organisational risk reduction solutions is pointed out, among others, by the author of [6], who emphasises the relatively low cost of their implementation.

The maintenance organisation method presented in the article may be rated among RBM methods and risk reduction measures. The RBM concept combines two types of issues, i.e. the issue of object maintenance and the issue of risk assessment. The implementation of risk assessment, also called risk evaluation, consists in verifying (by comparison, valuation) the risk category/class (acceptable, tolerable, non-acceptable) to which the risk specified during the hazard risk analysis belongs. The algorithm of risk evaluation is based on the results of calculations done with the use of the adopted model and is performed according to two procedures: pointing out the risk acceptability and risk valuation areas. It should be added that the task of all the undertakings is to achieve the level of risk in the acceptable risk category or - at least - the tolerable risk category, and to reduce it to the level below the non-acceptable risk category.

The fundamental problem is the appropriate combination of the issues of maintenance and risk assessment, and in particular, the development of proper risk measures and their use in streamlining maintenance. The analyses carried out, among others, in [10], demonstrated that risk conditioning in procedures connected with technical object maintenance, in particular railway vehicle maintenance, can be achieved by:

- the decision criterion - formulation of the form of the objective function of the decision-making problem based on the risk model;

- components of the objective function - taking account of the component concerning the risk of damage to technical objects 
or the so-called penalty function connected with the effects of damage to these objects in the formulated objective function;

- limiting the acceptable solution area by adopting the appropriate scope of variability of the decision variables.

It was assumed that the aim of this paper is to develop and present an RBM method consisting in the optimisation of the maintenance system of any technical object.

\section{The concept and principles of the presented method of optimisation}

In order to solve the problem, it is necessary to formulate the objective function of the decision-making problem based on the risk model or taking account of the component concerning risk. The relevance of this approach is also demonstrated by other authors (including [35]).

The form of the objective function was therefore based on the CURR (cost per unit risk reduction) index, whose model corresponds to both the possibilities referred to above. The description of the CURR index for the so-called risk control option (RCO) was presented, among others, in [26], and this is where its mathematical notation can be found, which is as follows:

$$
k_{\Delta R^{x} ; L}^{O S R}=\frac{\Delta K_{L}^{R C O}}{\Delta R_{L}^{x ; R C O}},
$$

where:

$$
\begin{aligned}
\Delta K_{L}^{R C O}- & \text { discounted increase in annual costs connected with } \\
& \text { the implementation of the given RCO relative to the } \\
& \text { base option within period } L(L \text { may be different than } \\
& \text { just the expected life cycle of the object }), \\
\Delta R_{L}^{x ; R C O-}- & \text { risk reduction for loss } x \text { within period } L \text { after the im- } \\
& \text { plementation of the RCO. }
\end{aligned}
$$
$\Delta R_{L}^{x ; R C O}-$ risk reduction for loss $x$ within period $L$ after the im- plementation of the RCO.

The use of the PM-type strategy primarily requires the specification of a certain threshold value of the number of work units for each of the object's elements after which the element becomes damaged. It is expressed in working time units, service life units, the number of starts, etc. The value may be determined e.g. based on the threshold value of tolerable risk.

With the threshold values of the number of work units of the elements at hand, one may search for the optimal number of units between object maintenances. The number of work units between object maintenances will therefore be a decision variable in the optimisation model. It was marked as $l$.

In the case of RBM methods, the number of work units between object maintenances is additionally conditioned by the expected value of risk reduction. As the authors of [15] put it: "Shutdown interval is one of the most important factors in determining an effective inspection and maintenance policy. In case if the shutdown inspection and maintenance interval is too short, object shutdown time and production loss along with the inspection and maintenance cost will be too high, vice versa if the shutdown interval is too long, the production loss and inspection and maintenance cost will be low but the risk exposure will be high" [15].

Therefore, the problem lies in the determination of the optimal number of work units between object maintenances and thus obtaining the optimal numbers of work units between object element maintenances.

Many problems of streamlining operation systems, including maintenance problems, may be boiled down to solving the tasks of static optimisation. They are usually tasks of non-linear optimisation with limitations. A review of the models of optimisation of technical object maintenance was presented, among others, by the author of [5], and examples of such models are presented, among others, by the authors of [35].

So treating the maintenance system as a point in a certain multidimensional Euclidean space, one may divide the set of this point's coordinates into two subsets: the variables called parameters, which are taken as constants in the process of configuring the maintenance cycle, and the decision variables whose values are modified. Taking into consideration the form of the selected CURR index, the threshold values of the number of work units and the costs of activities concerning the so-called risk handling procedures (taking an active attitude towards the identified hazards) were adopted as the parameters of the optimisation model. In the presented problem, it was assumed that such attitude involves preventive maintenance activities consisting in restoring the usability of the appropriate elements of the technical object under maintenance.

The number of work units between object maintenances and the number of work units between element maintenances were adopted as the decision variables. It is assumed that the number of work units between element maintenances is a multiple of the number of work units between object maintenances. The number of work units between element maintenances was marked as $l_{i}$.

Another issue concerns the link between the components of the risk model which was included in the objective function and the decision variables, i.e. the expression of the components of the risk model with the use of the decision variables. For this purpose, the generalised risk model presented by Kadziński, among others in [21], will be used. Subsequent versions of this model are published, among others, in [23].

The risk model for each hazard is a function of the components which are the result of separate decisions made based on the analysis according to $m$ criteria $K_{k}(k=1,2, \ldots, m)$. In accordance with the definition of risk, each of the $m$ analysis criteria has to be such that component $r_{k}\left(z_{i}\right)(k=1,2, \ldots, m)$, which is the result of a decision made according to this criterion, should belong to the group of components expressing the possibility of the activation of hazard $z_{i}(i=1,2, \ldots, n)$ or the size of the potential damage/losses resulting from its activation [21]. Thus defined, the risk may be the basis for formulating the criteria of optimisation of both the periods and scopes of preventive refurbishment [3,35].

When the levels of all the risk components are determined, the total risk $R$ of hazard $z_{i}(i=1,2, \ldots, n)$ may be notated as follows:

$$
R\left(z_{i}\right)=f_{1}\left(r_{1}\left(z_{i}\right), r_{2}\left(z_{i}\right), \ldots, r_{m}\left(z_{i}\right)\right), \quad i=1,2, \ldots, n
$$

where:

$n \quad-$ the number of identified hazards,

$m \quad-\quad$ the number of risk analysis criteria,

$z_{i} \quad-\quad i$-th hazard from the set of identified hazards,

$r_{k}\left(z_{i}\right) \quad-k$-th component of risk $z_{i}$ within the scope of the $k$-th risk analysis criterion.

And so the value of $R T$ (Risk Treatment) - the index of the procedure of handling the risk of hazard connected with the condition of the object's elements shall be the function of two components:

$$
R T=f\left(c_{i}, \Delta R_{i}\right)
$$

where:

$c_{i} \quad-\quad$ the cost of the procedure of handling the risk of the $i$-th hazard (generated by the condition of the $i$-th object element), 
$\Delta R_{i} \quad-\quad$ the value of the reduction of the risk of the $i$-th hazard achieved as a result of avoiding damage to the $i$-th object element.

Function $f$ defined in dependence (3) is adopted as the objective function of the decision-making problem.

As indicated before, the achievement of a level of risk below the non-acceptable risk category is satisfactory. It is best, however, if achieving and maintaining risk at the level of the acceptable risk category is possible. Between the two, there is the area of the tolerable risk category. Such division of the risk space is often adopted e.g. in the widely applied ALARP concept.

So let us assume that the reaction of the optimisation model will occur when the value of the risk of the $i$-th hazard $R_{i}$ is in the area of the tolerable risk category. This means that $\Delta R_{i}$, i.e. changes in the value of hazard risk reduction will be included in the following range:

$$
0 \leq \Delta R_{i} \leq R_{i}^{G T}-R_{i}^{D T}
$$

where:

$R_{i}^{D T}-$ lower limit of the area of the category of tolerable risk of the $i$-th object element,

$R_{i}^{G T}$ - upper limit of the area of the category of tolerable risk of the $i$-th object element.

In accordance with the principles concerning the risk model and dependence (2), among the components $r_{k}\left(z_{i}\right)(k=1,2, \ldots, m)$, at least one belongs to the group of components expressing the possibility of hazard activation. In the presented optimisation problem, the hazard connected with the condition of the object elements resulting from the number of work units (time) is subject to risk assessment. Thus, at least one ( $j$-th) of the components of the risk of the $i$-th hazard is dependent on the working time of the object element with which the hazard is connected.

One of the possible ways of expressing the possibility of hazard activation is the probability of the event where the condition of the working element will require the performance of maintenance activities after working for the $l$ number of work units. This can be notated as follows:

$$
r_{i j}=F_{i}(l)=P\left(L_{i}<l\right)
$$

where:

$L_{i} \quad-\quad$ random variable expressing the number of work units until the damage of the $i$-th object element,

$r_{i j} \quad-\quad j$-th component of the hazard risk of the $i$-th object element dependent on the $l$ number of work units.

For the purpose of this model, it was assumed that a single hazard is connected with damage to the $i$-th object element. Moreover - taking account of dependence (5) - is it suggested that the risk of this hazard should be notated as follows:

$$
R_{i}=f_{2}\left[r_{i 1}, r_{i 2}, \ldots, r_{i m-1}, F_{i}(l)\right], \quad i=1,2, \ldots, N
$$

where:

$N$

$R_{i}$
- the number of identified hazards equal to the number of object elements (table 4),

- the risk of hazard connected with the condition of the $i$-th object element requiring maintenance after the element having worked for $l$ work units.

For value $R_{i}$ of function $f_{2}$ equal to $R_{i}^{G T}$, there is a possibility of determining $l_{i}^{G T}$ - a threshold value of the number of work units of the $i$-th object element (example - table 4). The manner of determining this number was presented in [12]. If the threshold value $R_{i}^{G T}$ is unknown, the number $l_{i}^{G T}$ may be determined e.g. with the use of the model presented in [14].

It is also possible to determine a certain number $l_{i}^{D T}$, i.e. the threshold value of the number of work units of the $i$-th object element, after the exceeding of which, it is reasonable to perform maintenance. It is not justified, however, to plan this maintenance before $l_{i}^{D T}$, as the risk connected with the condition of the object element is acceptable at the time. Therefore, the range $\left\langle l_{i}^{D T} ; l_{i}^{G T}\right\rangle$ determines a practical scope of the value of the NWU of the $i$-th element of the object in which the decision about the need to perform maintenance is made, i.e.:

$$
l_{i}^{D T} \leq l_{i} \leq l_{i}^{G T}
$$

where:

$l_{i} \quad-\quad$ the number of work units between maintenances of the $i$-th object element.

Value $l_{i}^{D T}$ will serve to determine $\Delta R_{i}$ - reduction of the risk of the $i$-th hazard, achieved as a result of having anticipated damage to this element. Using dependences (4), (6), and (8), value $\Delta R_{i}$ shall be determined according to the following function:

$$
\Delta R_{i}=f_{3}\left(R_{i}\right)=\left\{\begin{array}{ccc}
f_{2}\left[F_{i}(l) \cong 0\right]-R_{i}^{\min } & \text { dla } & l_{i} \leq l_{i}^{D T} \\
f_{2}\left(l=l_{i}\right)-R_{i}^{\min } & \text { dla } & l_{i}^{D T}<l_{i} \leq l_{i}^{G T}
\end{array},\right.
$$

where $R_{i}^{\min }$ is the minimum value of risk and the beginning of the scope of the acceptable risk category. The value of risk is practically always larger than zero.

And so taking account of formulas (2), (6), and (8), in which function $f_{1}, f_{2}, f_{3}$ was defined, the objective function $f$ may be notated as follows:

$$
R T=f_{4}\left[c_{i}, f_{3}\left(R_{i}\right)\right] \Rightarrow R T=f\left\{c_{i}, f_{3}\left[f_{2}\left(r_{i 1}, r_{i 2}, \ldots, r_{i m-1}, F_{i}(l)\right)\right]\right\}
$$

Let us assume further that a single maintenance of the object consists in complete renewal of the operation potential of one or several of its elements at the same time. Such maintenance restores all the parameters to such a condition that the refurbished element may be treated as new. So there is a certain value $l^{*}-$ the value of the optimal number of work units between object maintenances which minimises the value of the objective function (9), i.e.:

$$
R T=f\left(l^{*}\right)=\min
$$

The manner of determining this value is presented in the detailed model described further on in the article. 


\section{The mathematical model}

At an initial stage of calculations, the $i(i=1,2, \ldots N)$ index assigned to the individual elements of the object shall be understood as the element's identifier resulting from a position series created according to the increasing $l_{i}^{G T}$, i.e.

$$
l_{1}^{G T} \leq l_{2}^{G T} \leq \ldots \leq l_{N}^{G T} .
$$

In accordance with dependence (11), the first maintenance of the element with identifier $i-1$ will be performed earlier than that of element $i$, which means that $l_{1} \leq l_{2} \leq \ldots \leq l_{N}$.

In the PM-type strategies, maintenances may be performed at fixed intervals. Moreover, the maintenance activities of the so-called lower order (usually occurring earlier and more frequently) are included within the scope of the maintenances of the higher order. This leads to the occurrence of certain dependencies between the values of the numbers of work units between maintenances of object elements. The values of these numbers, occurring later in the maintenance cycle, are a multiple of the numbers of work units between maintenances occurring earlier. This was notated with the introduction of the multiplicity factor $a_{i}$ assuming values from the set of positive integers:

$$
a_{i}=\operatorname{int}\left(\frac{l_{i}}{l_{i-1}}\right), \quad a_{i} \in \mathbf{C}(i=2, \ldots, N) .
$$

Value $a_{i}$ was used to express the number of work units between maintenances of elements with identifiers $i=2,3, \ldots, N$ :

$$
\begin{aligned}
& l_{2}=a_{2} l_{1} ; \\
& l_{3}=a_{3} l_{2}=a_{3} a_{2} l_{1} ; \\
& \quad \ldots \\
& l_{i}=a_{i} a_{i-1} \ldots a_{3} a_{2} l_{1} ; \\
& \quad \ldots \\
& l_{N}=a_{N} a_{N-1} \ldots a_{i-1} \ldots a_{3} a_{2} l_{1} .
\end{aligned}
$$

where:

- object element identifier resulting from the sequence in the position series created from value $l_{i}^{G T}$ (table 4),

$a_{i}(i=1,2, \ldots, N)$-multiplicity factor between the numbers of work units between maintenances of object elements $\left(a_{i} \in \mathbf{C}\right)$.

And so a certain vector $\mathrm{L}=\left[l_{1}, l_{2}, \ldots, l_{N}\right]$ of work units between maintenances of object elements which minimises the value of the objective function (9) is searched for. It will be called the vector of the decision variables of the optimisation model. Using dependences (10) and (13), one may notate this vector as follows:

$$
\mathrm{L}=\left[l_{1}, a_{2}, a_{3}, \ldots, a_{N}\right]
$$

And taking into consideration formulas (1) and (3) and dependences (13) and (14), the objective function $f$ may be initially expressed as follows:

$$
R T=f(\mathrm{~L})=\sum_{i=1}^{N} \frac{c_{i}}{\Delta R_{i}}
$$

with two limitations resulting from dependences (7) and (13):

$$
\begin{gathered}
0<l_{1} \leq l_{1}^{G T}, \\
0<l_{1} \cdot \prod_{v=2}^{i} a_{v} \leq l_{i}^{G T}, i=2,3, \ldots, N .
\end{gathered}
$$

Limitations (16) and (17) are linear functions, while function (15) is non-linear. The problem of determining the optimal number of work units between object maintenances may be solved using the methods of non-linear mathematical or dynamic programming [9], which is presented below.

If $q_{i}\left(l_{i}\right)$ is used to denote a component of the $R T$ index determined for the $i$-th hazard (of the $i$-th object element), i.e.:

$$
q_{i}\left(l_{i}\right)=\frac{c_{i}}{\Delta R_{i}}, i=1,2, \ldots, N
$$

the objective function $f$ may be expressed generally, in shortened form, as follows:

$$
f\left(l_{1}, a_{2}, a_{3}, \ldots, a_{N}\right)=\sum_{i=1}^{N} q_{i}\left(l_{i}\right)
$$

Using $R T^{*}$ to denote the minimum value of the index of the procedure of handling the risk of hazards concerning $N$ object elements and taking account of dependence (10), dependence (19), and the form of vector $\mathrm{L}$, one may note that:

$$
R T^{*}=f\left(l_{1}^{*}, a_{2}, a_{3}, \ldots, a_{N}\right)=\min _{l_{1} \in \Lambda_{1}, \ldots, l_{N} \in \Lambda_{N}}\left\{\sum_{i=1}^{N} q_{i}\left(l_{i}\right)\right\} .
$$

where $\Lambda_{i}$ are sets of the numbers of work units between object element maintenances, containing discrete values of variables $l_{i}$ $(i=1,2,3, \ldots, N)$. The problem of discretisation of the scope of values $l_{i}$ was presented in chapter 4 of the article.

Component $q_{1}\left(l_{1}\right)$ constitutes an invariable component of each of the values of acceptable solutions, and so it can be excluded from below the symbol min:

$$
f\left(l_{1}, a_{2}, a_{3}, \ldots, a_{N}\right)=q_{1}\left(l_{1}\right)+\min _{l_{2} \in \Lambda_{1}, \ldots, l_{N} \in \Lambda_{N}}\left\{\sum_{i=2}^{N} q_{i}\left(l_{i}\right)\right\} .
$$

Moreover, if it is assumed that the values of the components of the $R T$ index connected with the hazards concerning the condition of the elements with identifiers $i=2,3, \ldots, N$ are equal:

$$
\min _{l_{2} \in \Lambda_{1}, \ldots, l_{N} \in \Lambda_{N}}\left\{\sum_{i=2}^{N} q_{i}\left(l_{i}\right)\right\}=u_{2}\left(l_{2}\right)
$$

then taking account of formula (21), one may determine a certain function $w_{1}^{*}\left(l_{1}\right)$ - of the minimum RT values connected with the hazards concerning the condition of all the object elements $(i=2,3, \ldots, N)$ determined for any value $l_{1} \in \Lambda_{1}$ : 


$$
w_{1}^{*}\left(l_{1}\right)=q_{1}\left(l_{1}\right)+\min _{l_{2} \in \Lambda_{2}} u_{2}\left(l_{2}\right) .
$$

The optimal value of the $R T$ index for $N$ object elements will therefore equal::

$$
f^{*}=\min _{l_{1} \in \Lambda_{1}} w_{1}^{*}\left(l_{1}\right)
$$

In accordance with the methodology of dynamic or mathematical programming presented e.g. in [32], determining the minimum $R T$ value for $N$ technical object elements should begin with determining the minimum value of the $R T$ value for the element with identifier $i=N$ :

$$
u_{N}\left(l_{N}\right)=\min _{l_{N} \in \Lambda_{N}} q_{N}\left(l_{N}\right)=\min _{l_{N} \in \Lambda_{N}} \frac{c_{N}}{\Delta R_{N}}
$$

and then for subsequent elements with identifiers $i=N-1, N-2, \ldots, 1$.

The $R T$ value connected with the element with identifier $i=N-1$ depends on the value of the $R T$ component determined for the element with identifier $i=N$, i.e.:

$$
\begin{gathered}
u_{(N-1)}\left(l_{(N-1)}\right)=\min _{l_{N-1} \in \Lambda_{N-1}}\left[q_{(N-1)}\left(l_{(N-1)}\right)+u_{N}\left(l_{N}\right)\right], \\
\ldots \\
u_{i}\left(l_{i}\right)=\min _{l_{i} \in \Lambda_{i}}\left[q_{i}\left(l_{i}\right)+u_{i+1}\left(l_{i+1}\right)\right], \\
\ldots \\
u_{3}\left(l_{3}\right)=\min _{l_{3} \in \Lambda_{3}}\left[q_{3}\left(l_{3}\right)+u_{4}\left(l_{4}\right)\right], \\
u_{2}\left(l_{2}\right)=\min _{l_{2} \in \Lambda_{2}}\left[q_{2}\left(l_{2}\right)+u_{3}\left(l_{3}\right)\right] .
\end{gathered}
$$

The number of work units between maintenances of element $l_{1}$, for which the $R T$ value turned out to be the smallest, is also the optimal number of work time units between object maintenances. Based on this number and using dependence (13), one may determine the remaining optimal values $l_{i}^{*}(i=2,3, \ldots N)$.

\section{The scope of calculations and details of the math- ematical model}

Stage 1 - Adoption of the risk model and risk valuation model

For the purpose of the presentation of the scope of necessary calculations, using the results of works [21, 24], a detailed model of a risk analysis process for hazards connected with the condition of object elements was adopted. Within the model, two $(k=1,2)$ analysis criteria were adopted:

- $K_{1}$ - criterion of damage/losses suffered as a result of hazard activation,

- $K_{2}$ - criterion of the possibility of hazard activation.

An example of a pattern of quantification of the levels of damage/ losses resulting from hazard activation, within the scope of the first risk analysis criterion, was presented in table 1 . analysis criterion are determined in accordance with dependence (5). The basis for calculations is the data on object operation, including above all data on damage to elements. Knowledge of the wear processes which may lead to damage of these elements is also essential [35]. Such data for a sample object is presented in table 3.

In the detailed model of maintenance system optimisation, the following set of risk analysis criteria significance measures was adopted:

$$
A=\{2,1\},
$$

and the elements of the set of measures of the second risk component were assigned the following set of values:

$\Omega_{k}=\left\{\varpi_{i k}^{(j)}\right\}=\{0,250 ; 0,375 ; 0,500 ; 0,625 ; 1,000\}, i=1,2, \ldots, n ; j=1,2, \ldots, 5 ; k=1$.

The last issue is the selection of the form of function $f_{2}$ - dependence (6), which makes it possible to determine value $R_{i}$. It may be determined in the form of a mathematical function, tabularly, with a graph, verbally or otherwise. Apart from the levels of risk components, risk analyses also take into account the significance measures of the analysis criteria, and one of the most frequent dependences is (29):

$$
R_{i}=\prod_{k=1}^{m} \alpha_{i k} \cdot r_{i k}, i=1,2, \ldots, N
$$

or dependence (30) taking into account the results of hazard risk analysis according to two criteria and the significance measures of the hazard risk analysis criteria:

$$
R_{i}=\sum_{k=1}^{2} \alpha_{i k} \cdot r_{i k}, i=1,2, \ldots, N
$$

where $\alpha_{i k}$ are the significance measures of risk components within the scope of the $k$-th criterion of risk analysis. Such form of the risk function is applied in many known methods. For example, in the risk score method risk model and the failure mode and effects analysis method, three components $(k=3)$ and a set of measures of their significance $\mathrm{A}=\{1 ; 1 ; 1\}$ are applied. 
So using dependences (9), (15), and (19), the objective function $R T$ values shall be expressed in formula (31):

$$
R T=\sum_{i=1}^{N} \frac{c_{i}}{\alpha_{m} B_{i} \cdot \prod_{k=1}^{m-1} \alpha_{i k} \cdot r_{i k}-R_{i}^{\min }},
$$

where $B_{i}$ is a component of the objective function dependent on the distribution of probability describing the number of work units until the damage of the $i$-th element. These may be typical probability distributions. It might e.g. be initially assumed that element maintenance occurs in the period of their age-related damage, which would be very advantageous from the point of view of the effectiveness of the maintenance system operation. For in this period, damage is usually characterised by normal probability distribution. In such case, the form of the objective function $f$ may e.g. be as follows:

$$
R T=\sum_{i=1}^{N} \frac{c_{i}}{\frac{\alpha_{m}}{\sigma_{i} \cdot \sqrt{2 \cdot \Pi}} \cdot \int_{-\infty}^{l_{i}} e^{-\frac{\left(l_{i}-\mu_{i}\right)^{2}}{2 \cdot \sigma_{i}^{2}}} \cdot d l \cdot \prod_{k=1}^{m-1} \alpha_{i k} \cdot r_{i k}-R_{i}^{\min }},
$$

or otherwise:

$$
R T=\sum_{i=1}^{N} \frac{c_{i}}{\alpha_{m} \cdot F_{i}^{N(\mu ; \sigma)}\left(l_{i}\right) \cdot \prod_{k=1}^{m-1} \alpha_{i k} \cdot r_{i k}-R_{i}^{\min }}
$$

where:

$F_{i}^{N(\mu ; \sigma)}\left(l_{i}\right)$ - value of the cumulative distribution function of the number of work units until the damage of the $i$-th object element with normal distribution, determined for the number of work units between element maintenances $l_{i}$,

$\mu_{i} \quad-$ expected value of the number of work units until the damage of the $i$-th object element,

$\sigma_{i} \quad-$ standard deviation of the number of work units until the damage of the $i$-th object element.

Stage 2 - Identification of hazards generated by damage to object elements

Hazard identification is a separate issue and due to its complexity, it will not be raised in this article. A proposal of the implementation of a hazard identification process can be examined in the following publications of the author of this article: [18-20]. The result of the hazard identification process is the so-called hazard record.

Stage 3 - Estimation and valuation of the risk of hazards generated by the condition of object elements

In the presented optimisation model, the risk level space was divided into three areas. The pattern of this valuation is presented in table 2 .

When the risk level is included in the area of the non-acceptable or tolerable risk category, risk handling procedures, i.e. maintenance activities should be implemented.

Due to the adopted ranges of risk levels (table 2), two extreme cases concerning the determination of $l_{i}^{G T}$ based on value $R_{i}$ may occur in the calculation process. The first case consists in the fact that the value of risk $R_{i}$ will always be in the $\mathrm{A}$ area, i.e. the acceptable
Table 2. Pattern of risk valuation in the model of optimisation of the technical object maintenance system

\begin{tabular}{||c|c|c||}
\hline $\begin{array}{c}\text { Range of values } \\
\text { of risk measures }\end{array}$ & $\begin{array}{c}\text { Range of risk } \\
\text { levels }\end{array}$ & $\begin{array}{c}\text { Name of the risk category area } \\
\text { and its symbol }\end{array}$ \\
\hline$\left[R_{i}^{\min }, R_{i}^{D T}\right)$ & {$[0.50 ; 1.40)$} & $\begin{array}{c}\text { Acceptable risk category area - } \\
\text { symbol A }\end{array}$ \\
\hline$\left[R_{i}^{D T}, R_{i}^{G T}\right]$ & {$[1.40 ; 1.60]$} & $\begin{array}{c}\text { Tolerable risk category area - } \\
\text { symbol T }\end{array}$ \\
\hline$\left(R_{i}^{G T}, R_{i}^{\max }\right]$ & {$[1.60 ; 3.00]$} & $\begin{array}{c}\text { Non-acceptable risk category } \\
\text { area - symbol NA }\end{array}$ \\
\hline
\end{tabular}

Source: own elaboration based on [21]

risk category, regardless of value $r_{i 2}$ - risk component expressing the possibility of hazard activation. This happens when the level of damage/losses resulting from hazard activation is very low (e.g. level 1 - "green").

The second case consists in the fact that the value of risk $R_{i}$ will always be in the NA area, i.e. the non-acceptable risk category, also regardless of value $r_{i 2}$. This is the case when the first of the components of risk $r_{i 1}$ assumes the highest values of damage/loss measures, e.g. values at the "red" level (table 2).

The threshold values of the number of work units of elements may be obtained based on values $R_{i}^{D T}$ and $R_{i}^{G T}$. And so $r_{i 2}^{D T}$ shall be a certain threshold value of the second component obtained based on value $R_{i}^{D T}$. Assuming that risk $R_{i}$ is given with dependence (30), it may be notated that:

$$
r_{i 2}^{D T}=\frac{R_{i}^{D T}-\alpha_{i 1} \cdot r_{i 1}}{\alpha_{i 2}}
$$

and using dependence (5):

$$
r_{i 2}^{D T}=F_{i}^{N(\mu, \sigma)}\left(l_{i}^{D T}\right),
$$

hence:

$$
F_{i}^{N(\mu, \sigma)}\left(l_{i}^{D T}\right)=\frac{R_{i}^{D T}-\alpha_{i 1} \cdot r_{i 1}}{\alpha_{i 2}} \Rightarrow l_{i}^{D T}=F_{i}^{-1 N(\mu, \sigma)}\left(\frac{R_{i}^{D T}-\alpha_{i 1} \cdot r_{i 1}}{\alpha_{i 2}}\right)
$$

Knowing that the cumulative distribution function of the number of work units until the damage of the $i$-th object element has normal distribution, it may be assumed that:

$$
F_{i(\max )}(l)=F_{i}^{N(0 ; 1)}(3)
$$

In the first case, concerning the determination of $l_{i}^{G T}$, when the value of risk $R_{i}$ will always be in area A, there is no need to "hurry" with performing the maintenance of the object element. In the second case, when the value of risk $R_{i}$ will always be in area NA, element maintenance should be performed as soon as possible. Within the scope of the detailed model and the adopted form of function (15) or (20), and in particular in the form of the cumulative distribution function, a solution in the following form is suggested: 


$$
\begin{gathered}
l_{i}^{D T}=\left\{\begin{array}{ccc}
\mu_{i}-3 \sigma_{i} & \text { dla } & r_{i 2} \cong 0 \\
F_{i}^{-1}\left(\frac{R_{i}^{D T}-\alpha_{i 1} \cdot r_{i 1}}{\alpha_{i 2}}\right) & \text { dla } & 0<r_{i 2}<1 \\
\mu_{i}+3 \sigma_{i} & \text { dla } & r_{i 2} \cong 1
\end{array}\right. \\
l_{i}^{G T}=\left\{\begin{array}{ccc}
\mu_{i}-3 \sigma_{i} & \text { dla } & r_{i 2} \cong 0 \\
F_{i}^{-1}\left(\frac{R_{i}^{G T}-\alpha_{i 1} \cdot r_{i 1}}{\alpha_{i 2}}\right) & \text { dla } & 0<r_{i 2}<1 \\
\mu_{i}+3 \sigma_{i} & \text { dla } & r_{i 2} \cong 1
\end{array}\right.
\end{gathered}
$$

The cases referred to above do not have to occur with differently adopted risk valuation patterns.

Stage 4 - Determining the ranges of values of the decision variables of the optimisation model

Determining the ranges of values of the decision variables of the model primarily serves the execution of calculations in the form of a simulation. This is required by the research problem posed, and in particular the non-linear form of the objective function.

The value of variable $l_{1}$ is a real number from the range of $\left\langle l_{1}^{D T} ; l_{1}^{G T}\right\rangle$. And so discretisation of the range of values $l_{1}$ is introduced, i.e. a certain step of simulations/calculations $\Delta l$ is adopted and it is assumed that $l_{i}^{D T}=\Delta l . \Delta l$ can also be interpreted as the accuracy of the calculations.

Discretisation of the range of values $l_{1}$ and the multiplicity between object maintenances (dependence (13)) lead to the formation of distinctive sets of decision variables, i.e. sets of possible numbers of work units between element maintenances.

And so $\Lambda_{i}$ shall be the sets of possible numbers of work units between element maintenances which are defined as follows:

- $\quad$ for $i=1$

$$
\Lambda_{1}=\left\{l_{1(j)}\right\}, j=1,2, \ldots, m_{1} \text {, where } l_{1(j)}-l_{1(j-1)}=\Delta l(39)
$$

where:

$l_{i(j)} \quad$ is the $j$-th possible value of the number of work units between maintenances of the $i$-th element.

$j \quad-$ is the identifier of the next possible value of the number of work units between maintenances of the $i$-th element, which belongs to set $\Lambda_{1}$,

$m_{1} \quad-$ is the size of set $\Lambda_{1}$ equal to:

$$
m_{i}=\operatorname{int}\left(\frac{l_{1}^{G T}}{\Delta l}\right),
$$

- $\quad$ for $\mathrm{i}>1$

$$
\Lambda_{i}=\left\{l_{i(k)}\right\}, k=1,2, \ldots, n_{i}
$$

where:

$n_{i} \quad-\quad$ is the size of set $\Lambda_{i}$ dependent on value $l_{1(j)}$ as follows:

$$
n_{i}=\operatorname{int}\left(\frac{l_{i}^{G T}}{l_{1(j)}}\right) \text {, }
$$

and:

$l_{i(k)} \quad-\quad$ is the $k$-th possible value of the number of work units between maintenances of the $i$-th element, such that:

$$
\underset{i>1}{\forall} \forall \underset{k}{\forall} l_{i(k)}=k \cdot \prod_{v=2}^{i} a_{v-1} \cdot l_{1(j)},
$$

Figure 1 presents, among others, the manner of determining sets $\Lambda_{i}$ for four elements of a sample technical object and one of the values $l_{1(j)}$.
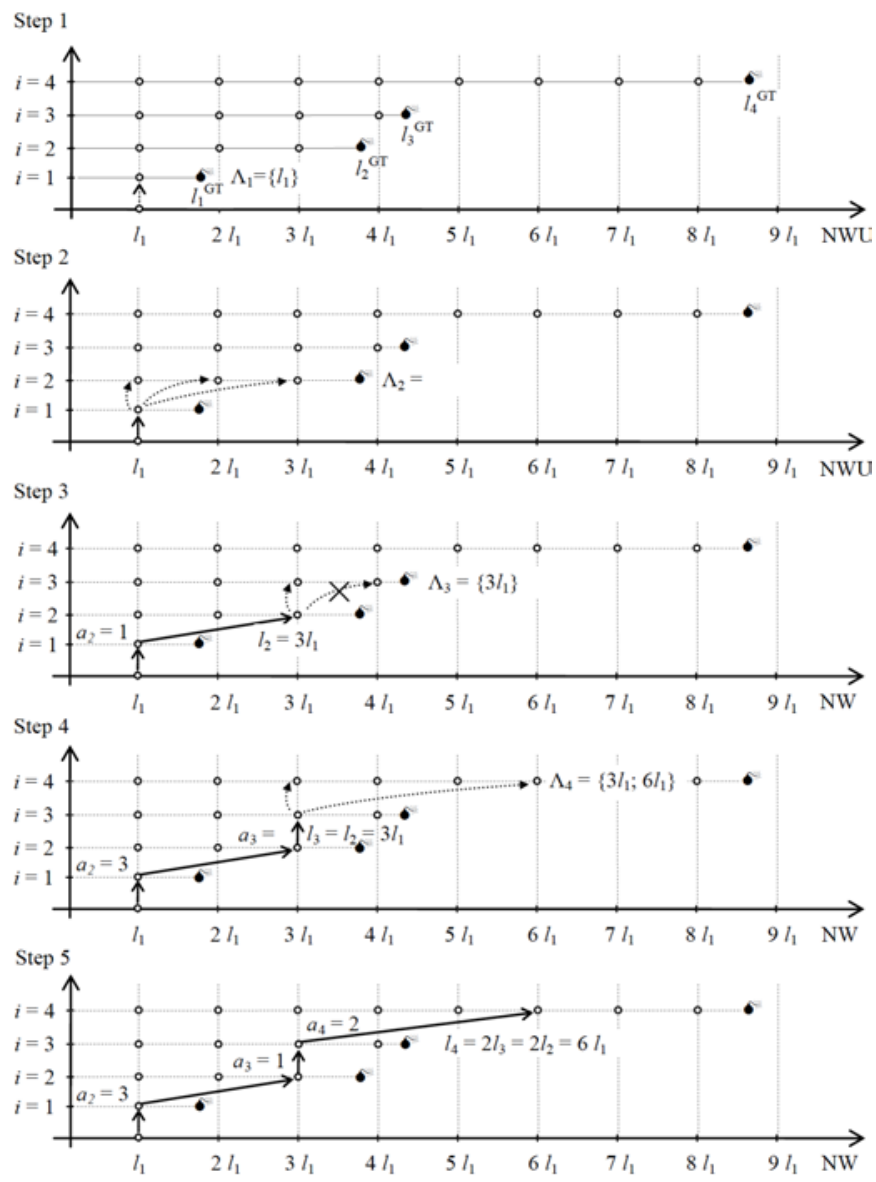

Fig. 1. Diagram of obtaining a sample solution acceptable in the optimisation of the number of work units (NWU) between technical object maintenances for four elements of this object and one of the values $l_{l}$

So assuming that $i=4, j=1$ and that the decision variables assume values as presented in figure 1, i.e.: $a_{1}=1, a_{2}=3, a_{3}=1, a_{4}=2$, sets $\Lambda_{i}$ will be as follows:

$$
\begin{aligned}
& \Lambda_{1}=\left\{l_{1(1)}\right\} \\
& \Lambda_{2}=\left\{l_{2(1)} ; l_{2(2)} ; \ldots ; l_{2\left(n_{2}\right)}\right\}=\left\{a_{1} l_{1(1)} ; 2 a_{1} l_{1(1)} ; \ldots ; n_{2} a_{1} l_{1(1)}\right\}=\left\{l_{1(1)} ; 2 l_{1(1)} ; 3 l_{1(1)}\right\} \\
& \Lambda_{3}=\left\{l_{3(1)} ; l_{3(2)} ; \ldots ; l_{3\left(n_{3}\right)}\right\}=\left\{a_{2} a_{1} l_{1(1)} ; 2 a_{2} a_{1} l_{1(1)} ; \ldots ; n_{3} a_{2} a_{1} l_{1(1)}\right\}=\left\{3 l_{1(1)}\right\} \\
& \Lambda_{4}=\left\{l_{4(1)} ; l_{4(2)} ; \ldots ; l_{4\left(n_{4}\right)}\right\}=\left\{a_{3} a_{2} a_{1} l_{1(1)} ; 2 a_{3} a_{2} a_{1} l_{1(1)} ; \ldots ; n_{3} a_{3} a_{2} a_{1} l_{1(1)}\right\}=\left\{3 l_{1(1)} ; 6 l_{1(1)}\right\}
\end{aligned}
$$

Using dependence (26), one may properly notate the dependences of individual components of the $R T$ value. The notation of these values in individual points of the graph presented in figure 1 and for one value $l_{1(j)}$ (e.g. $\left.j=1\right)$ will be as follows: 
- $\quad$ for $i=1$

$$
\left.u_{1}\left(l_{1}=l_{1(1)}\right)=q_{1}\left(l_{1(1)}\right)+\min _{l_{2} \in \Lambda_{2}=\left\{l_{1(1)} ; 2 l_{1(1)} ; 3 l_{1(1)}\right.}\right\}\left(l_{2}\right)
$$

- $\quad$ for $i=2$

$$
\begin{aligned}
& u_{2}\left(l_{2}=l_{2(1)}=l_{1(1)}\right)=q_{2}\left(l_{1(1)}\right)+\min _{l_{3} \in \Lambda_{3}=\left\{l_{1(1)} ; 2 l_{1(1)} ; 3 l_{1(1)} ; 4 l_{1(1)}\right\}} u_{3}\left(l_{3}\right) \\
& u_{2}\left(l_{2}=l_{2(2)}=2 l_{1(1)}\right)=q_{2}\left(2 l_{1(1)}\right)+\min _{l_{3} \in \Lambda_{3}=\left\{2 l_{1(1)} ; 4 l_{1(1)}\right.} u_{3}\left(l_{3}\right) \\
& u_{2}\left(l_{2}=l_{2(3)}=3 l_{1(1)}\right)=q_{2}\left(3 l_{1(1)}\right)+\min _{l_{3} \in \Lambda_{3}=\left\{3 l_{1(1)}\right\}} u_{3}\left(l_{3}\right)
\end{aligned}
$$

- $\quad$ for $i=3$

$u_{3}\left(l_{3}=l_{3(1)}=l_{1(1)}\right)=q_{3}\left(l_{1(1)}\right)+\operatorname{lin}_{l_{4} \in \Lambda_{4}=\left\{l_{(1)} ; 2 l_{(1)} ; 3 l_{(1)} ; 4 l_{1(1)} ; 5 l_{(1)} ; 6 l_{(1)} ; 7 l_{(1)} ; 8 l_{1(1)}\right.} u^{u_{4}\left(l_{4}\right)}$

$u_{3}\left(l_{3}=l_{3(2)}=2 l_{1(1)}\right)=q_{3}\left(2 l_{1(1)}\right)+\operatorname{lin}_{l_{4} \in \Lambda_{4}=\left\{2 l_{1(1)} ; 4 l_{1(1)} ; 6 l_{1(1)} ; 8 l_{1(1)}\right\}} u_{4}\left(l_{4}\right)$

$u_{3}\left(l_{3}=l_{3(3)}=3 l_{1(1)}\right)=q_{3}\left(3 l_{1(1)}\right)+\min _{l_{4} \in \Lambda_{4}=\left\{3 l_{1(1)} ; 6 l_{1(1)}\right.} u_{4}\left(l_{4}\right)$

$u_{3}\left(l_{3}=l_{3(4)}=4 l_{1(1)}\right)=q_{3}\left(4 l_{1(1)}\right)+\min _{l_{4} \in \Lambda_{4}=\left\{4 l_{(1)} ; 8 l_{(1)}\right\}} u_{4}\left(l_{4}\right)$

- $\quad$ for $i=4$

$u_{4}\left(l_{4}=l_{4(k)}\right)=q_{4}\left(l_{1(k)}\right), k=1,2, \ldots, 8$

As a result, the first value of component $w_{1}\left(l_{1}=l_{1(1)}\right)$ of the $R T$ index obtained according to the formula presented in figure 1 can be obtained in the following manner:

$$
w_{1}\left(l_{1}=l_{1(1)}\right)=q_{1}\left(l_{1(1)}\right)+q_{2}\left(3 l_{1(1)}\right)+q_{3}\left(3 l_{1(1)}\right)+q_{4}\left(6_{1(1)}\right) .
$$

Another step of the calculations is the determination of value $w_{1}\left(l_{1}\right)$ for the remaining values $l_{1(j)}$, i.e. for $j=2,3, \ldots m_{1}$.

\section{Application of the optimisation model for a sample object}

An example of optimisation was presented for certain elements of a tram. The most frequently damaged elements of various tram systems were selected. Their damage usually causes the tram to stop. The condition of the elements changes as a result of wear and/or it is relatively difficult or unprofitable to monitor the technical condition of these elements.

Information about damage to selected elements of the tram was presented in the form of appropriate characteristics (table 3). It was obtained based on the data (collected for the purposes of the Municipal Transport Company (MPK)) on the times and reasons for the so-called emergency returns to depot. The data is from the period of three years during which the trams were operated in normal working conditions. Their working time expressed in days was selected as a variable characterising the life cycle of the elements. Hypotheses on the form of the probability distributions of this time were verified with the use of the Statistica 12 program, assuming the level of significance of 0.05 .

The parameters of the optimisation model were presented in table 4. In order to determine them, the identification of hazards (stage 2 , chapter 4) connected with damage to selected elements was performed, and the formulated hazards were provided in column 5 of table 4. The hazards were given identification numbers ("H_") corresponding to identifier $i$ of the elements.

Next, guided by the principles of the adopted risk model (stage 1 , chapter 4 ), the values of one of the risk components were adopted (column 6, table 4). This made it possible to determine values $l_{i}^{G T}$ (column 8, table 4) in accordance with dependence (38) with known function $F_{i}(l)$, given with the proper probability distribution (table 3).

On account of the complexity of the calculations (stage 4, chapter 4) and a specific character of the optimisation problem, it was decided that a dedicated computer application for the optimisation model should be developed. It makes it possible to do calculations in the form of simulation for theoretically any number of object elements with assumed simulation/calculation step $\Delta l$. Figure 2a presents the diagram of the structure of maintenance cycles and a chart of the values of the objective function for the object adopted for the presented

Table 3. Characteristics of selected tram elements

\section{Characteristics of distribution matching}

Descriptive statistics of the element's working time

Item

\section{Element name}

Number of im- Number of Average Standard plementations cars value deviation

\section{Probability distribution} type
Degrees of Chi-squared Statistical freedom statistics value significance $p$
Resistance lamination

1 sheets of the GBT-373 starter

Current collector contact shoe

Current converter motor brushes

4 Brake lever mechanism

Universal joint

120.3005

Log-normal

13

19.25974

0.11527

164

55

189.6890

182.3782

Exponential

9

10.28231

0.32812

54

12

68.55556

62.30953

Log-normal

3

1.94371

0.58417

608

35

51.93092

75.09104

Log-normal

14

19.48904

0.14709

44

29

221.6364

237.6264

Exponential

8

13.54065

0.09455

R15 transmitter

60

25

149.9000

175.7922

Log-normal

3

4.61922

0.20190

Door controller

49

25

168.7959

194.0156

Exponential

2

2.99906

0.22324

Electronic starting transmitter (EST)

64

37

210.4063

201.1366

Exponential

6

6.75927

0.34368 
Table 4. Parameters of the optimisation model of the technical object maintenance system

\begin{tabular}{|c|c|c|c|c|c|c|c|}
\hline Item & $i^{*}$ & $\begin{array}{l}\text { Element name / (type of } \\
\text { maintenance activity) }\end{array}$ & ID $* *$ & $\begin{array}{l}\text { Hazard connected with damage } \\
\text { to tram element }\end{array}$ & $\begin{array}{c}\text { Value of the meas- } \\
\text { ure of risk compo- } \\
\text { nent expressing } \\
\text { damage/losses } \\
\text { after hazard acti- } \\
\text { vation } \\
r_{i 1}\end{array}$ & $\begin{array}{l}\text { Cost ci of } \\
\text { risk handling } \\
\text { procedures } \\
\text { expressed in } \\
\text { time losses } \\
\text { [min] }\end{array}$ & $\begin{array}{c}\text { Threshold value of } \\
\text { the number of work } \\
\text { units for the ele- } \\
\text { ment } \\
l_{i}^{G T} \\
\text { [days] }\end{array}$ \\
\hline 1 & 2 & 3 & 4 & 5 & 6 & 7 & 8 \\
\hline 1 & 5 & $\begin{array}{l}\text { Resistance lamination } \\
\text { sheets of the GBT-373 } \\
\text { starter/(replacement) }\end{array}$ & BO & $\begin{array}{l}\text { H5 - risk of tram stopping while } \\
\text { in use }\end{array}$ & 0.250 & 360 & 448.01 \\
\hline 2 & 4 & $\begin{array}{l}\text { Current collector contact } \\
\text { shoe/(replacement) }\end{array}$ & so & $\begin{array}{l}\text { H4 - risk of traction network dam- } \\
\text { age }\end{array}$ & 0.375 & 180 & 359.86 \\
\hline 3 & 2 & $\begin{array}{l}\text { Current converter motor } \\
\text { brushes/(replacement) }\end{array}$ & SS & $\begin{array}{l}\mathrm{H} 2 \text { - risk of tram stopping while } \\
\text { in use }\end{array}$ & 0.250 & 60 & 255.48 \\
\hline 4 & 1 & $\begin{array}{l}\text { Brake lever mechanism/ } \\
\text { (adjustment) }\end{array}$ & MD & $\begin{array}{l}\text { H1 - risk of extending the braking } \\
\text { distance }\end{array}$ & 0.500 & 240 & 70.96 \\
\hline 5 & 9 & $\begin{array}{l}\text { Universal joint/(replace- } \\
\text { ment) }\end{array}$ & PK & $\begin{array}{l}\text { H9 - risk of tram stopping while } \\
\text { in use }\end{array}$ & 0.250 & 420 & 934.52 \\
\hline 6 & 6 & $\begin{array}{l}\text { R15 transmitter/(re- } \\
\text { placement) }\end{array}$ & PR & $\begin{array}{l}\text { H6 - risk of tram stopping while } \\
\text { in use }\end{array}$ & 0.250 & 120 & 677.28 \\
\hline 7 & 3 & $\begin{array}{l}\text { Door controller/(replace- } \\
\text { ment) }\end{array}$ & SD & $\begin{array}{l}\text { H3 - risk of passenger being hit } \\
\text { and/or knocked over }\end{array}$ & 0.375 & 300 & 320.23 \\
\hline 8 & 7 & $\begin{array}{l}\text { Electronic starting trans- } \\
\text { mitter (EST)/(replace- } \\
\text { ment) }\end{array}$ & PE & $\begin{array}{l}\mathrm{H} 7 \text { - risk of tram stopping while } \\
\text { in use }\end{array}$ & 0.250 & 960 & 813.82 \\
\hline 9 & 8 & $\begin{array}{l}\text { Door mechanism cam/ } \\
\text { (adjustment) }\end{array}$ & KM & $\begin{array}{l}\mathrm{H} 8 \text { - risk of doors not closing prop- } \\
\text { erly preventing the tram from } \\
\text { departing }\end{array}$ & 0.250 & 120 & 896.96 \\
\hline
\end{tabular}

- identifier of object element resulting from the increasing threshold values of the numbers of work units of elements

${ }^{* *}$ - identifier of the element in the maintenance cycle structure diagram

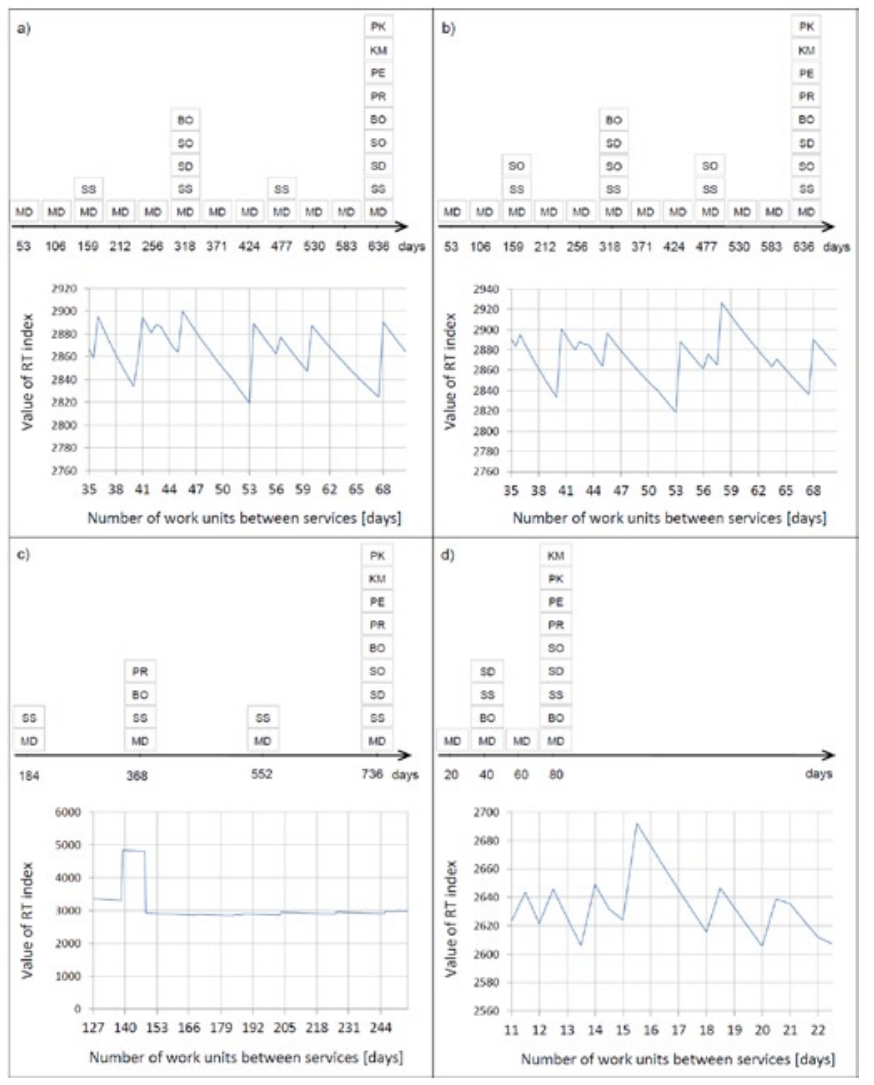

Fig. 2. The results of determining the optimal structure of the maintenance cycle with the use of the optimisation model for different variants of input data (abbreviations - as in table 4). example. The value of the risk handling procedure index for the optimal solution was $R T=2819.17$.

Figures $2 b, 2 c$, and $2 d$ present the "reaction" of the model to changes within its main parameters, i.e. changes in the value of the measure of risk component expressing damage/losses resulting from hazard activation.

In the case of calculations presented in figure $2 b$, the reaction of the optimisation model to changes significant from the point of view of risk estimation, but small in the sense of changes in the values of the model parameters. A situation involving damage to current collector (pantograph) of the tram and parts of the overhead contact line resulting from the wear of the graphite cover (contact shoe) was analysed. This was mapped in the model, increasing the value of component $r_{41}$ to 0.500 . A transfer of the symbol of this element "SO" in the cycle structure and its more frequent occurrence can be observed. The value of the risk handling procedure index for this solution was $R T=2818.45$.

The solutions presented in figures $2 \mathrm{c}$ and $2 \mathrm{~d}$ concern typically theoretical calculation cases. The threshold (minimum and maximum) values of the measure of risk component expressing damage/losses after hazard activation were used there. And so, for the calculation case in figure $2 \mathrm{c}$, minimum values $r_{i 1}=0,250$ for all $(i=1,2, \ldots, 9)$ object elements and/or all the hazards were introduced, and then the maximum values, i.e. $r_{i 1}=0,625$, for the case in figure $2 \mathrm{~d}$. The values of the risk handling procedure index for optimal solutions obtained in calculation cases c) and d) in figure 2 were: $R T=2848.46$ and $R T=2605.70$, respectively. Considerable changes in the value of the time interval between individual object maintenances should be noted. 


\section{Conclusions}

The problem of the optimisation of the technical object maintenance system taking account of risk requires proper formulation of the objective function. It may be based on the risk model or take account of the component concerning risk. In the method developed here, an original form of the objective function was formulated. Its components are risk handling procedure costs and the values of reducing the risk measure obtained as a result of avoiding damage to object elements. In the objective function of the optimisation process, a risk model based on two criteria was applied: the criterion of damage/ losses suffered as a result of hazard activation and the criterion of the possibility of these hazards' activation. Within the scope of the first criterion, a finite set of damage/loss value levels is used. The second criterion is dependent on the object's working time. Its values are expressed by the probability of the event in which the element requires maintenance activities after having worked for a specific number of working time units. It was assumed that the risk measure model is a sum of the products of risk components according to individual criteria and the significance of these criteria.

The process of making maintenance-related decisions is armed with procedures based on a risk valuation pattern. The author's original risk valuation pattern was used, classifying risk into three categories (acceptable, tolerable, and non-acceptable). When the risk measure value is included in the area of the non-acceptable or tolerable risk category, risk handling procedures (maintenance activities) should be implemented. Special cases of risk valuation resulting from the use of the patterns applied were discussed.

The structure of the maintenance cycles in preventive strategies renders the objective function of the decision-making problem discontinuous. It is therefore suggested to solve the problem with the use of dynamic programming methods. For this purpose, a mathematical notation of such modelling was developed and presented. It is a relatively difficult task to determine the range of values that the decision variables may assume in this modelling. The problem was illustrated by showing a formula for obtaining a sample acceptable solution. Moreover, a formal/mathematical notation of generating value ranges of decision variables was presented.

The complexity of the formulated optimisation task required computer assistance in order to obtain solutions. A dedicated computer program was developed and with its use, solutions to the task of optimisation of the process of planning maintenance of selected tram devices were obtained. The results of the optimisation were also prepared and their visualisation carried out with the use of the program. The program also makes it possible to check the "reaction" of the optimisation model to parameter changes. Above all, changes significant from the point of view of risk estimation, but small in the sense of changes in the values of the parameters were checked. Among others, a situation involving damage to the current collector (pantograph) of the tram and parts of the overhead contact line resulting from excessive wear of the current collector's graphite cover (contact shoe) was analysed. A significant change in the structure of the maintenance cycle and a change in the value of the $R T$ index was observed. This leads us to believe that the prepared method will make it possible to solve decision-making problems concerning: the manner, scope, and schedules of replacements, repairs, and regular maintenance of technical object elements, the manner and schedules of diagnosing and preventive replacement of elements, and the problems of providing the maintenance subsystem with spare parts.

\section{Acknowledgement}

The research work financed with the means of statutory activities of Faculty of Machines and Transport Poznan University of Technology 05/52/DSPB/0259.

\section{References}

1. Amundrud Ø, Aven T. On how to understand and acknowledge risk. Reliability Engineering and System Safety 2015; 142: 42-47, http:// dx.doi.org/10.1016/j.ress.2015.04.021.

2. Brennan F. Risk Based Maintenance for Offshore Wind Structures. Procedia CIRP 2013; 11: 296-300, http://dx.doi.org/10.1016/j. procir.2013.07.021.

3. Carazas F G, Souza G F M. Risk-based decision making method for maintenance policy selection of thermal power plant equipment. Energy 2010; 35: 964-975, http://dx.doi.org/10.1016/j.energy.2009.06.054.

4. Commission Implementing Regulation (EU) 2015/1136 of 13 July 2015 amending Implementing Regulation (EU) No 402/2013 on the common safety method for risk evaluation and assessment, 2015: Official Journal of the European Union.

5. Dekker R. Applications of maintenance optimization models: a review and analysis. Reliability Engineering and System Safety 1996; 51: 229-240, http://dx.doi.org/10.1016/0951-8320(95)00076-3.

6. Dickerson D E, Ackerman P J. Risk-based Maintenance Management of U.S. Public School Facilities. Procedia Engineering 2016; 145: 685-692, http://dx.doi.org/10.1016/j.proeng.2016.04.069.

7. Flage R, Aven T. Emerging risk - Conceptual definition and a relation to black swan type of events. Reliability Engineering and System Safety 2015; 144: 61-67, http://dx.doi.org/10.1016/j.ress.2015.07.008.

8. Fujiyamaa K, Nagaia S, Akikunib Y, Fujiwarab T, Furuyab K, Matsumotob S, Takagib K, Kawabatac T. Risk-based inspection and maintenance systems for steam turbines. International Journal of Pressure Vessels and Piping 2004; 81: 825-835, http://dx.doi.org/10.1016/j. ijpvp.2004.07.005.

9. Gill A. Metoda wyznaczania struktury cyklu napraw elementów pojazdów szynowych. Pojazdy Szynowe 2004; 3-4: 38-42.

10. Gill A. Procedury decyzyjne w obsługiwaniu obiektów systemów technicznych uwzględniające analizę ryzyka. [rozprawa doktorska], Poznań: Politechnika Poznańska, 2007.

11. Gill A, Kadziński A. Metoda organizacji systemu obsługiwania obiektów pojazdów szynowych uwzględniająca poziom nienaruszalności bezpieczeństwa. Organizacja transportu szynowego, in: XVII Konferencji Naukowej “Pojazdy Szynowe 2006”, Kazimierz Dolny 2006: 575-585.

12. Gill A, Kadziński A. System obsługiwania pojazdów szynowych jako element w warstwowym modelu ich systemów bezpieczeństwa. Pojazdy Szynowe 2006; 4: 31-38.

13. Gill A, Kadziński A. Warunkowanie ryzykiem w procedurach decyzyjnych w obsługiwaniu pojazdów szynowych. Logistyka 2009; 6: CD.

14. Gill A, Kadziński A. The determination procedure of the onset of the object wear-out period based on monitoring of the empirical failure intensity function. Eksploatacja i Niezawodność - Maintenance and Reliability 2015; 17 (2): 282-287, http://dx.doi.org/10.17531/ ein.2015.2.16. 
15. Hameed A, Khan F, Ahmed S. A risk-based shutdown inspection and maintenance interval estimation considering human error. Process Safety and Environmental Protection 2016; 100: 9-21, http://dx.doi.org/10.1016/j.psep.2015.11.011.

16. Hu J, Zhang L. Risk based opportunistic maintenance model for complex mechanical systems. Expert Systems with Applications 2014; 41: 3105-3115, http://dx.doi.org/10.1016/j.eswa.2013.10.041.

17. Moradkhani A, Haghifam M R, Abedi S M. Risk-based maintenance scheduling in the presence of reward penalty scheme. Electric Power Systems Research 2015; 121: 126-133, http://dx.doi.org/10.1016/j.epsr.2014.12.006.

18. Gill A. The concept of safety system for the selected hazards identified in tram communication. Technika Transportu Szynowego 2015, 10: 2065-2074.

19. Gill A, Kadziński A. Hazard identification model. Proceedings of 20th International Scientific Conference Transport Means 2016; 5-7 Oct. Juodkrante, Lithuania: 885-890.

20. Gill A, Kobaszyńska-Twardowska A. Identyfikacja zagrożeń w wybranych strefach tramwaju z wykorzystaniem metody Bow-Tie. Logistyka 2014; 6: 5514-5521.

21. Kadziński A. Studium wybranych aspektów niezawodności systemów oraz obiektów pojazdów szynowych. Poznań: Wyd. Politechniki Poznańskiej, Rozprawy series, no. 511, 2013.

22. Kadziński A, Gill A. Integracja pojęć. In: Krystek R, editor. Zintegrowany system bezpieczeństwa transportu. Warszawa: WKE, 2009: 285-288.

23. Kadziński A, Warguła J, Gill A, Szacowanie i wartościowanie ryzyka zagrożeń związanych z odcinkiem szybkiego tramwaju na poznańskiej sieci tramwajowej. Logistyka 2012; 3: 939-948.

24. Kadziński A, Woźniak A. O modelach kwantyfikacji zagrożeń bezpieczeństwa w transporcie kolejowym, in: Mat. XIV konferencji naukowej "Pojazdy szynowe"; Kraków-Arłamów, 2000: 129-136.

25. Khan F I, Haddara M R. Risk-based maintenance of ethylene oxide production facilities. Journal of Hazardous Materials 2004; 108(3): 147-159, http://dx.doi.org/10.1016/j.jhazmat.2004.01.011.

26. Kosmowski K T. Metodyka analizy ryzyka w zarządzaniu niezawodnością i bezpieczeństwem elektrowni jądrowych. Gdańsk: Wydawnictwo Politechniki Gdańskiej, 2003.

27. Młyńczak M, Pisarski P. Wspomaganie komputerowe w prognozowaniu obsług obiektów mechanicznych: Metody prognozowania w inżynierii niezawodności, in: Mat. XXXI Zimowej Szkoły Niezawodności; Szczyrk, 2003: 356-364.

28. Nilsson F. Risk based approach to plant life management. Nuclear Engineering and Design 2003; 221(1-3): 293-300, DOI: 10.1016/S00295493(02)00334-5.

29. Nielsen J J, Sørensen J D. On risk-based operation and maintenance of offshore wind turbine components. Reliability Engineering and System Safety 2011; 96: 218-229, http://dx.doi.org/10.1016/j.ress.2010.07.007.

30. Niu G, Yang B, Pecht M. Development of an optimized condition-based maintenance system by data fusion and reliability-centered maintenance. Reliability Engineering and System Safety 2010; 95: 786-796, http://dx.doi.org/10.1016/j.ress.2010.02.016.

31. Niziński S. Eksploatacja obiektów technicznych. Radom: Wydawnictwo i Zakład Poligrafii Instytutu Technologii Eksploatacji, 2002.

32. Ochodek B, Ochodek M. Algorytmy i struktury danych. Piła: Państwowa Wyższa Szkoła Zawodowa w Pile, 2003.

33. Okulewicz J, Salamonowicz T. Porównanie wybranych strategii odnów profilaktycznych. In: Mat. XXXIV Zimowej Szkoły Niezawodności, 2006: 218-227.

34. Ponchet A, Fouladirad M, Grall A. Assessment of a maintenance model for a multi-deteriorating mode system. Reliability Engineering and System Safety 2010; 95: 1244-1254, http://dx.doi.org/10.1016/j.ress.2010.06.021.

35. Rusin A, Wojaczek A. Optimization of power machines maintenance intervals taking the risk into consideration. Eksploatacja i Niezawodność - Maintenance and Reliability 2012; 14 (1): 72-76.

36. Sarkar A, Panja S H, Sarkar B. Survey of maintenance policies for the Last 50 Years. International Journal of Software Engineering \& Applications (IJSEA) 2011; 2(3)130-148.

37. Straub D, Faber M H. Risk based inspection planning for structural systems. Structural Safety 2005; 27: 335-355, http://dx.doi.org/10.1016/j. strusafe.2005.04.001.

38. Tang D, Yu J, Chen X, Makis V. An optimal condition-based maintenance policy for a degrading system subject to the competing risks of soft and hard failure. Computers \& Industrial Engineering 2015; 83: 100-110, http://dx.doi.org/10.1016/j.cie.2015.02.003.

39. Wang L, Chu J, Mao W. A condition-based order-replacement policy for a single-unit system. Applied Mathematical Modelling 2008; 32: 2274-2289, http://dx.doi.org/10.1016/j.apm.2007.07.016.

40. Zio E. Reliability engineering: Old problems and new challenges, Reliability Engineering \& System Safety 2009; 94(2): 125-141, http:// dx.doi.org/10.1016/j.ress.2008.06.002.

\section{Adrian GILL}

Institute of Combustion Engines and Transport

Poznan University of Technology

Piotrowo 3, 60-965 Poznan, Poland

E-mail: adrian.gill@put.poznan.pl 